\title{
Chronological Study of Iran-U.S Relations (1785-1997)
}

\author{
Baharak Partowazar (Corresponding author) \\ Faculty of Human Ecology, Universiti Putra Malaysia (UPM) \\ Malaysia \\ E-mail: baharakpartowazar@yahoo.com
}

Fakhreddin Soltani

Faculty of Law and Political Science, Islamic Azad University of Karaj

Iran

Received: September 21, 2016 Accepted: October 24, 2016 Published: November 28, 2016

doi:10.5296/jpag.v6i4.10333 URL: http://dx.doi.org/10.5296/jpag.v6i4.10333

\begin{abstract}
Relationship between Iran and the United States started with a Trade Agreement during Qajar dynasty during Amir Kabir chancellorship, though formal diplomatic relationship was not established until 1944.During Pahlavi dynasty, their relationship improved and after the Islamic revolution their relationship transformed into the hostility. Therefore, Iran-U.S relation has experienced complex changes. This article attempts to study major shifts in Iran-U.S relations since Qajar dynasty until the end of Rafsanjani presidency in the Islamic Republic of Iran.
\end{abstract}

Keywords: Coup, Sanction, Hostage Crises 


\section{Introduction}

Mir Abdul-Latif was the first Iranian who wrote a fictional book about the United States. In his book, he explained how Christopher Columbus discovered the United States. Mirza Saleh Shirazi traveled to England and published his newspaper Kaghaz-e Akhbar -Persian translation of the word "newspaper"- in May 1837, under the autocratic regime Mohammad Shah Qajar. In his newspaper, he explained about the United States (www.iran-newspaper.com, 2013). Also in 1832, Christian missionaries were the first Americans who travelled to Iran. They went to Isfahan to preach their religion but people did not accept them. The other missionaries travelled to Oromiye. They improved their activities and established schools and a scientific and medical university in that city.

The political relationship between the United States and Iran goes back to the 19th century when Nasereddin Shah Qajar was the King of Iran and Amir Kabir was a reformer chancellor of Iran. He wanted to countervail the power of Russia and Britain by close relationship with the United States. He predicted that this country will be a world power in future (Mohammadpour, 2012). In 1850, Amir Kabir ordered the Iranian ambassador in Turkey to sign a friendship and shipping treaty with the United States (Ghaneabassiri, 2002). By this agreement their consulate opened and the first official ambassador of Iran in Washington D.C was Mirza AbolhassanShirazi. Britain opposed the agreement and Amir Kabir one month after the agreement was killed by British conspiracy in order to neutralize it. Another prime minister canceled the agreement. Five years later Iran and Britain had challenge about Afghanistan Farrokh Khan Amin Aldoleh and by the order of chancellor renewed the treaty in Istanbul. This agreement was signed by Nasereddin Shah and Franklin Pierce in 1857. Because of the British influence in Iran this agreement was not applied for more than 25 years (www.iran-newspaper.com, 2013).

In 1883, during Arthur presidency, Benjamin was the United States ambassador in Iran. During a three-year period, he could not apply his plans such as the construction of a railroad for Iran. In this period with the increasing power of Russia and the United Kingdom in the region, Iran wanted to establish relationships with countries such as the United States to balance the power in the region.

In 1911, Morgan Shuster, American lawyer, civil servant, and publisher who is best known as the treasurer-general of Persia (Mojani, 1996) was instructed by President Taft $-27^{\text {th }}$ President of the United States- by appointment of the Iranian parliament to try to organize Iran's financial system but the British and General Liakhov of Russia showed their opposition to the United States. Shuster was not the official representative of the United States and he worked in Iran in a private capacity. His work was stopped in 1912 under pressure from the UK and Russia (Samii, 1987). Formal ambassadorial relations between the United States and Iran were not established until 1944 (Lesch, 2007).

According to Deldom "some other historians argue that the reason why Iran was eager to employ the American mission was to create a third power through which they could be released from the pressure of Russia and England. The truth is that towards the beginning of $20^{\text {th }}$ century, the United States was interested in Iran because of the discovery of oil rich 
resources in the south of Iran. The Americans made their first attempt to control financial affairs through the Morgan Shuster mission” (Deldom, 1992).

After World War I, Iran tried to establish close relationships with the United States and also supported the United States President Woodrow Wilson's Fourteen Points. In August 1919, an agreement drafted by the British government was signed between Iran and the United Kingdom in Tehran. By this agreement Iran was turned into a British protectorate. Prior to signing this agreement, the Iranian Prime Minister, Vosoq al-Dawleh, and two of his colleagues in the cabinet, Nosrat al-Dawleh (Firuz) and Sarem al Dawleh (Laali, Zarifinia, Zibakalam, \& Khazayee) secretly negotiated with Sir Percy Cox, the temporary minister in Tehran, and the British Foreign Secretary, George Nathaniel Curzon about this agreement (Sabahi, 1990). This agreement was strongly opposed by public in Iran but the opposition was not confined to public. France, Bolshevik Russia, and the United States also showed their disapproval of this agreement. Eventually the agreement failed to get approved in the Majlis and was abandoned (Katouzian, 2006).

On February 18, 1921, Reza Khan, who was an officer in the Qajar Cossack Brigade successfully invaded Tehran in a bloodless coup. The coup established Reza Khan as an important political figure. Ahmad Shah was formally deposed by the Majlis on October 1925 while he was in Europe (Cronin, 1994). According to Zirinsky, the British participated in the coup. Both Reza and Zia later claimed to have been its chief architect. At the time, British and American observers saw the coup as Zia's. Reza's role seemed minor. Norman's first reports indicated that Reza was only one of three military leaders, that he acted on behalf of Zia, and that he had no political ambition. Afterward, Reza claimed to have been in charge all along, but that has not been supported by contemporary evidence. Much later, Commander General Ironside claimed to have "engineered the coup d'état" on Reza's behalf. While there is no reason to doubt that he recognized Reza's ability and encouraged him. In his published diary is written that Reza was only one of several plotters. But of all the conspirators, only Reza retained power (Zirinsky, 1992).

\section{Iran-US Relations during the Pahlavi Dynasty (1925-1979)}

During World War II, the United States had the closest relationship with Iran among the allies. In 1942 Iran and the United States signed an agreement on training of the Iranian police by the United States (Ladjevardi, 1983). The person who was appointed to do the job was Norman Schwarzkopf who was posted to Iran after the UK-Soviet intervention (Eisenhower, 1991).

Also, on January 29, 1943, an American named Millspaugh was appointed by the Majlis to reorganize the Iranian economy and financial systems. During the years between 1942 and 1945 General Greely, who was in charge of the American troops in Iran, Dreyfus, the United States ambassador in Tehran, Schwarzkopf, and Millespaugh all worked together (Ladjevardi, 1983). The Soviet Union did not cooperate with Millspaugh in the areas that were under its control (Amin, 2001). This made it hard for Millspaugh to work. In addition to Soviet's opposition to him he also had to deal with the opposition of the Iranian press and in the Majlis. Eventually, Millspaugh resigned February 1945 and left the country(Millspaugh, 
1946).

Another major political interaction between the United States and Iran happened in 1951 during the confrontation between the UK and Iran over the nationalization of oil. On 22 August 1951, the United Kingdom imposed economic sanctions against Iran. After nationalization law went into effect in Iran in May 1951, the British asked the United States for cooperation to invade Iran (Moaddel, 1989). The United States resolutely opposed the British plan. And the United States ambassador, Acheson warned Franks, the British ambassador in the United States about invading Iran. (Kinzer, 2003).

Because of the sanctions, Iran's Prime Minister, Mosaddeq faced a lot of problems. He decided to ask the United States for help. Although Truman wanted to help Iran but because of pressure from the British, the US could not support Mosaddeq. Mosaddeq requested help from the World Bank but his effort failed. In August 1952, Mosaddeq invited the United States oil executive, Jones, to visit Iran. Truman was in favor of this idea but Churchill reminded Truman of the British support for the United States in Korea, and the British expectations of the United States to support the "Anglo-American unity". Churchill opposed any friendly relationship between Iran and the United States (Kinzer, 2003).

\section{The Coup against Mohammad Mosaddeq}

In 1953 Eisenhower replaced Truman as the president of the United States. During his presidency, Truman did not join the British campaign against Mosaddeq but after Eisenhawer's election the political climate in the United States changed drastically. To the United States Iran was important for its oil and its long border with the Soviet Union. Iran also was important for political reasons: its prime minister was a true nationalist and its communist party, Tudeh, was pretty active. The United States, under Eisenhower, believed that Iran would fall to communism and it could be a serious danger for the United States (Kinzer, 2003).

After Mosaddeq nationalized the Anglo-Iranian Oil Company (AIOC), in November 1952, two weeks after the United States presidential election, the Central Intelligence Agency (CIA) station in Iran started their activities against Mosaddeq. The United States and British planned for a coup, named "Ajax", or as CIA named it TPAJAX. The key figures in planning the operation were "John Foster Dulles, the incoming Secretary of State, and Allen Dulles, the incoming CIA director"(Kinzer, 2003). Another member of the coup against Iran was Kermit Roosevelt, the CIA chief in part of the Near East and Asia and Donald Newton Wilber, who was a Roosevelt colleague and the architect of TPAJAX (Fayazmanesh, 2003b). After his arrival to Iran Roosevelt met the Shah. In their meeting he told the Shah that "leaving Mosaddeq in power would lead only to a Communist Iran or to a Second Korea, which Western leaders were not prepared to accept"(Kinzer, 2003).

The Shah agreed to work with the CIA according to the plan and signed two Firmans (royal decrees) in August 1953 (Gasiorowski, 1987). One Firman dismissed Mosaddeq from his role as the prime minister. The other one appointed General Fazlollah Zahedi as the new prime minister. The Shah flied to Ramsar on the Caspian coast after issuing the Firmans(Kinzer, 
2003). On Saturday, August 15, Colonel Nasiri delivered the Shah's Firman to Mosaddeq. On the same day, the Todeh party, who learned about the coup earlier informed Mosaddeq about it (Gasiorowski, 1987). Iran's chief of staff, General Riahi, arrested Nassiri and denounced him as a traitor before sending him to jail.

Later, Mosaddeq went on the air to announce that the plan arranged by the Shah and foreign elements had failed. The Shah immediately flew to Baghdad, and later to Rome. Roosevelt should have left Iran, but instead he decided to stay in Tehran and never left until he had completed the execution of the plan. Later, Roosevelt met Zahedi at his home and asked him to cooperate with him in his plan and to try again to seize power. Roosevelt hid Zahedi at the Villa of a fellow agent, three blocks from the United States embassy.

Roosevelt brought two Persian journalists code-named, Nerren and Cilley, to meet Zahedi (Fardust and Dareini, 1999). In the meeting, Zahedi informed them about the Firmans. The report by these journalists was published in the New York Times and other newspapers. Roosevelt made sure to have certain lies spread through the reports: lies like the story about Mosaddeq trying to seize the Shah's dominion and how patriotic officers thwarted Mosaddeq's actions. These lies were published on the front page of American newspapers. Only a few journalists doubted the story and suggested that Mosaddeq was not the instigator of the coup but the victim of it (Kinzer, 2003).

Over two days Roosevelt's agents bribed politicians, mullahs, and anyone that was able to turn out crowds at a crucial moment. He also sent mobs into the street to create mayhem in Mossadeq name. Mosaddeq did not allow the police officers to interfere. On Tuesday thousands of unknown protesters under CIA's control, took to the streets, damaging the shops, destroying the Shah's pictures and looting the royalist groups' offices (Roosevelt, 1979)."Exuberant nationalists and communists joined in the mayhem". Since Mosaddeq had not ordered police to stop the riot earlier, when he ordered the police to attack the mob most of his fervent supporters were among those arrested. It is important to mention that Roosevelt paid Ayatollah KashaniUS $\$ 10,000$ to use his religious influence on the faithful to limit Mosaddeq's support (Kinzer, 2003).

Finally, on August 19, thousands of people gathered in the Mosques and public squares. The crowd included outlandish athletes, and rascals, Ayatollah Kashani's supporters, and former criminals, armed with knives and homemade clubs, shouted "Long live the Shah" and "Death to Mosaddeq". A group of rioters attacked and burned three offices of pro-governmental newspapers such as Akhbar-e-Emruz and eight government buildings. Also they attacked the foreign ministry, the general staff headquarters, and the central public station. Bribed police officers encouraged the mob and supported them. According to Cottom, the Operator Ajax staff in Washington, "That mob that came into north Tehran was decisive in the overthrow was a mercenary mob"(Afkhami, 2009). Leaders of the Tudeh party tried to help Mosaddeq but he did not trust them because he believed the Tudeh party was controlled by the Soviet Union.

Mobs attacked Mosaddeq's home and destroyed everything, but they could not find him. Mosaddeq already had left the house but he could not hide for long, so he turned himself in to 
Zahedi's government. Shortly after the Shah's return to Iran Mosaddeq was imprisoned for three years and later was placed under house arrest in the village of Ahmad-Abad until his death in March 1967 (www.hamshahrionline.ir, 2009).

After the coup, on several occasions President Eisenhower and Shah expressed their intention to improve the alliance between Iranians and Americans. Shah used a two-fold policy in order to increase his control on the government while keeping it closely aligned with the goals and objectives of the United States. In similar manner the United States began to court Iran (Ramazani, 1982).

After the coup Eisenhower introduced his doctrine promising to help any Middle East countries that protected its sovereignty against the threats of communism. In March 1959 the American Ambassador in Iran, Helms, convinced Iran to sign a defense agreement with the United States in order to solidify the United States position in the region. In addition the United States promised to defend Iran against any aggression (Ramazani, 1982).

In April 1961, a reformer, Amini succeeded Sharif-Emami. The Kennedy administration approved and supported the Prime Minister Amini on his intended major social and administrative reforms. Amini had a strong relationship with the United States especially during the Kennedy administration from 1961-1963. It was "important to American strategic and economic interests in the era to have an Iranian government with a broader internal base, greater efficiency and popularity, and less corruption than existed in the 1950s"(Keddie, 2003).

In 1963, the Shah introduced his reform program as the "White Revolution"(Keddie, 2003).The reforms faced opposition among the clerical community (Seikal, 1980) and led by Ayatollah Khomeini, who was mostly against the land reforms and women's right to vote (1963). The riots were crushed and Khomeini was arrested (Mottahedeh, 2000).

On June 3, 1963, Khomeini made a speech against the Shah at Feyziyeh Madreseh in Qom. In Qom he was arrested and transferred to Qasr prison in Tehran. He was released on April 7, 1964 and returned to Qom (Moin, 1999).

On October 13, 1964 the Parliament passed the capitulation law for the United States armed forces in Iran. After his release from jail Khomeini reacted to the law in a speech in Qom criticizing Iran's relationship with the United States (Shirley, 1999). In his speech he declared that "They have reduced the Iranian people to a level lower than that of an American dog. If someone runs over a dog belonging to an American, he will be prosecuted. Even if the Shah himself were to run over a dog belonging to an American, he would be prosecuted. But if an American cook runs over the Shah, the head of state, no one will have the right to interfere with him"(Husain, 1988).Consequently he was arrested and later was exiled to Iraq for 14 years (Moin, 1999).

In the late 1960s and the early 1970s Nixon tried to strengthen the patron-client relationship with regional powers in order to protect the United States interests. Due to the fact that Iran had one of the longest coastlines on the Persian Gulf Iran was important to the United States and would serve as the United States client in the region (Kissinger, 2011). The United 
States-Iran relationship seemed to be very much to the benefit of the United States. Part of Iran's income of oil sale to the United States was paid back by exporting military equipment to Iran. Both Nixon and Kissinger (Secretary of State) blinded their eyes on the shah's domestic policies and believed that Iranians and Americans shared the same interests. According to Kissinger "On all major international issues, the policies of the United States and the policies of Iran have been parallel and therefore mutually reinforcing" (Kissinger, 2011). Kissinger characterized the Shah as the "rarest of leaders, an unconditional ally, and one whose understanding of the world situation enhanced our own" (Kissinger, 2011). As Kissinger influenced the Nixon and Ford administrations they let the Shah promote his interests in the Middle East because the Shah's interests were convergent with the United States interests in the Middle East. "Nixon allowed the shah to assume the regional leadership role that he had always sought for Iran" (Alvandi, 2012).

The American influence increased under the Ford administration. Despite President Nixon's resignation, his deputy, Kissinger, continued on as the secretary of State and the ford administration increased arms sales to Iran. In a cable to the Shah in 1974 the Secretary of State, Kissinger, suggested that both countries "broaden and deepen" their relations. He suggested that the nations improved their relations by enhancing Iran's petrochemical industry, increasing Iran's satellite technology, and by collaborating on expansion of Iran's nuclear power program. The parameters would include a Joint American Commission at the Cabinet level that would foster collaboration in the various areas mentioned above. The Shah was naturally receptive to Kissinger's suggestions and had aspirations that U.S would allow Iran to be the site of choice to manufacture American missiles. Others within the Ford administrations, such as Secretary of Defense Schlesinger were more skeptical of Kissinger's blank check policy to the Shah. Schlesinger's doubts were considered by the President, especially in light of the rising oil prices. However, President Ford continued to rely on Kissinger for foreign policy advice over others.The shah visited Washington in 1975 and was praised as a man of “extraordinary ability and knowledge”(Shawcross, 1989).

After the Shah's departure the United State Congress allowed the Ford administration the free access of American military equipment to Iran. In this exchange of arms it appears that that the Shah exploited the United States' fears of communism at the time: Was it possible for the United States, and the Free world to continue their struggle against communism without Iran? Didn't they get more nuclear holocausts or more Vietnams if they did not pay attention to their friends? In response Kissinger promised the Shah unlimited access to American arms (Shawcross, 1989).

In 1975, the Shah turned the country into a one-party system by establishing a politically-uncontested party named Hezb e Rastakhiz e Mellat e Iran, or the Party of Iranian Nation's Resurgence, widely known as Hezb e Rastakhiz (Resurgence Party)(Todd and Marty, 2005). According to Coughlin (2010), from this moment on "all facets of political life would come under the supervision of movement; all citizens were required to join the party and vote in national elections, and those who refused were denounced as 'traitors' or 'secret Communists' and given the choice of either going to prison or leaving the country for the Soviet Union"(Coughlin, 2010). 
Domestic pressure against the Shah's authoritarian rule and his one-party system came from various opposition groups: certain members of the clergy, such as Khomeini and his followers, Marxist guerrilla movements such as the Sazaman-e Cherikha-ye Feda'iKhalq-e Iran (The Organization of the Iranian Peoples' Guerrilla Freedom Fighters) and Sazman-e Mujahedin-e Khalq-e Iran (The Organization of the Iranian Peoples' Freedom Fighters), and the Iranian nationalist and the socialist intelligentsia in general (Abrahamian, 1982). The criticisms of the opposition not only targeted the Shah but the United States government and its support of the Iranian government.

In October 1964, Khomeini spoke against the presence of the United States military advisors and the "capitulation" law (or "status-of-forces agreement") that allowed members of the United State armed forces in Iran to be tried in their own military courts. This was a political stand supported by various political opposition groups either, secular nationalists, socialists, Marxists, or Islamists. Later in the 1970s, several United States military officials were assassinated in Iran by the armed guerrillas who opposed the Shah's policies and the United States Republican administrations' support for him (Abrahamian, 1982).

During the 1970-1977 period Iran had one of the worst human rights records in the world (Afkhami, 2009). Political prisoners were tortured by the Iranian secret police, Savak, using acts such as "sleep deprivation; extensive solitary confinement; glaring searchlights; standing in one place for hours on end; nail extractions; snakes (favored for use with women); electrical shocks with cattle prods, often into the rectum; cigarette burns; sitting on hot grills; acid dripped into nostrils; near-drowning; mock executions; and an electric chair with a large metal mask to muffle screams. Prisoners were also humiliated by being raped, urinated on, and forced to stand naked." (Abrahamian, 1999)

By 1976 and with the rise of the Democratic Party to power in the United States the U.S. policy toward Iran drastically changed. Under pressure from President Jimmy Carter the Shah restrained Savak's activities and released political prisoners (Abrahamian, 1982). The Shah started a series of political liberalization policies that were named Fazaye Baze Siyasi or "Open Political Space" (Afkhami, 2009). But the opposition did not believe in the sincerity of the Shah's attempts and saw them as efforts to placate Washington.

The Shah made some changes to the cabinet, changed the military prosecution law, allowed limited freedom of the press to criticize the government, and finally replaced his prime minister of 13 years, Hoveyda, with a new figure, Amuzegar. Despite the Shah's hopes of gaining some support among the opposition these efforts were not accepted by the majority of the critics in Iran. The opposition was suspicious of the Shah's liberalization policies, seeing them as cosmetic changes on a regime that could not be reformed. In the U.S., on the other hand, President Carter was convinced by the Iranians that the Shah's attempts to liberalize Iran had been relatively successful.

On December 31, 1977, when President Carter was the Shah's guest for New Year's Eve, Iran and the United States reaffirmed their relationship "the first guest in the new year is an omen for that year. We consider it an excellent omen, the Shah said, while President Carter reciprocated with his infamous, "Iran is an island of stability in one of the most troubled areas 
of the world. This is a tribute to the respect the people give you."(Shawcross, 1989).

During the revolutionary movement by Khomeini's leadership, the Shah faced a division in Carter's administration. The State Department led by Cyrus Vance suggested negotiations with the opposition. National Security Advisor, Brzezinski, believed that in order to restore the control of the country it was necessary for the United States to support the Shah. These different signals from the United States and other reasons put the Shah in paralysis and indecision. On January 16, 1979 the Shah left Iran forever and a few months later the Islamic revolution overthrew the Shah's rule (Brzezinski., 1983).

\section{The Islamic Republic and US relations (1979-1989)}

The Islamic revolution in 1979 changed the dynamics of the political relationships between the two countries. In September 1979, Bazargan, the Iranian Prime Minister, and Yazdi, the Foreign Minister, met with the United States secretary of state, Cyrus Vance, at the United Nations (Hunter, 1990). In November 1979, Bazargan also met the U.S. National Security Advisor,Brzezinski, in Algeria.

Following a liberal foreign policy, Bazargan tried to maintain Iran's relationship with the United States but the hardliner religious factions within the government and newly-established revolutionary institutions and also the leftist organizations put pressure on Bazargan's government to end any kind of relationship with the United States.

\section{The Hostage Crises during Bazargan's Government}

On 4 November 1979 a student organization called "The Muslim student followers of the Imam's line" attacked the United States embassy in Tehran, occupied the embassy buildings, and took its personnel hostage for 444 days (Farber, 2009). During the occupation the members of the group searched for top secret documents in the embassy and found many of them shredded. During the next few months after the hostage taking by "The Muslim student followers of the Imam's line" glued together many of the shredded documents, many of them secret and top-secret correspondence with the United States government. "The Muslim student followers of the Imam's line" eventually published the recovered documents in 70 volumes (http://www.gwu.edu., 1999).

They tried not to deal with the United States as an enemy, but their action led to the collapse of Bazargan's government. Keddie believes that "Bazargan's government worked to improve political and economic relations with the United States, which in many ways reciprocated. But when influential Americans convinced President Carter to allow the ex-shah to come to the United States from Mexico for cancer treatment despite the Provisional Government's warnings, the situation changed dramatically"(Keddie, 2003).

About three months after the collapse of Bazargan's government, Bani-Sadr was elected as the first president of Iran. Bani-Sadr tried to find a way to release the hostages. In opposition to Bani-Sadr, Khomeini "saw in the crisis an opportunity to humble the United States and to undermine its image and prestige, thus encouraging other Muslims to rise up against Americans. This fitted his long-term objective of demonstrating that the United States was no 
longer omnipotent and that Muslim nations should not fear challenging its supremacy"(Hunter, 1990).

On 24 April 1980 the United States president, Carter, ordered a military mission to rescue the hostages. "[E]ight Sea stallions ... helicopters lifted off from the elongated deck of the aircraft carrier Nimitz ... Their orders were to fly North west to a remote landing strip 275 miles from Tehran. There would rendezvous with six C-130 Hercules transport planes carrying the commandos, vans, and trucks assigned to storm the American embassy in Tehran to rescue the hostages. The helicopters hit a sandstorm that disabled two and sent a third crashing into one of the C-130. Both aircrafts burst into flames. With eight servicemen dead, the rescue mission ended, leaving the hostages in place" (Mackey and Harrop, 1998). This event gave Khomeini the opportunity to mobilize his followers against the United States and whoever supported having any relationship with the United States.

Multiple, pressure factors such as the death of the Shah on July 27, the Iraqi invasion of southern and western Iran on 22 September, the United States sanctions and the consequent international isolation of Iran led Khomeini to secretly negotiate with the U.S. during the fall of 1980. As a result of the negotiations, Khomeini declared some conditions. His conditions included: "a pledge by the United States not to intervene in Iran's affairs; the return of Iranian assets frozen in the United State; the cancellation of U.S. claims; and the return of the Shah's wealth. Soon, secret negotiations between Iran and the United States began"(Keddie, 2003). Khomeini kept the Iranian president uninformed about the negotiations so Bani-Sadr did not know about the process until it was announced publicly(Keddie, 2003). On $21^{\text {th }}$ January 1981, after the United States president left his office, Iran released the hostages (Farber, 2009). Later on in February Bani-Sadr accused his opponents of deliberately keeping him uninformed about the hostage negotiations (Hindy, 1981).

The Iran Hostage Crisis effectively stopped the relationship between the two countries. In the United States the event hurt the American national pride. In response the United States announced a series of sanctions against Iran. The United States seized Iranian assets in the United States, put Iran under economic embargo, and limited visa issuance to Iranian visitors (Fayazmanesh, 2003a).

\section{Iran-Iraq War}

After the Hostage Crisis, during the Iran-Iraq war the United States stayed neutral, but many actions it took showed that it was sympathetic toward Iraq. In addition to the help from the Western powers, Saddam Hussein also was assisted by its Arab neighbors and the Persian Gulf states. The Persian Gulf states gathered in Abu Dhabi - the capital of United Arab Emirates - and formed the Gulf Cooperation Council (GCC) in 1981 to protect their governments from the Iranian threats of "the export of revolution" (Kechichian, 1989). Their action was because in the immediate days after the revolution Khomeini's stand on foreign policy was to export the revolution. Khomeini shortly after taking power declared "we should try hard to export our revolution to the world...we [shall] confront the world with our ideology" (Ehteshami., 1995). In addition, Iran's constitutions called on its military forces to "extend the sovereignty of God's law throughout the world" (Bakhash, 1985). Expressing 
such claims about exporting the revolution created an atmosphere of hostility between Iran and its neighbors. In response the neighboring countries decreased their economic connections and trade with Iran and some supported the Iranian opposition groups (Byman, 2008).

During the Iran-Iraq war, Iran faced economic problems, a shortage of weapons, and the decrease of oil prices. In order to solve these problems, Rafsanjani-the pragmatic parliamentary speaker - by Khomeini's permission used American hostages, arrested by Shi'a military in Lebanon, to secretly negotiate with the Reagan Administration about exchanging the American hostages for weapons. Rafsanjani told Americans that Iran could use its "influence" to release the hostages but in return Iran expected them to provide Iran with weapons. To send Iran the weapons the United States used Israel as a transit station. All of these connections happened secretly. Some years later the negotiations leaked out and the scandal was named the Iran-Contra Affair (Yazdani and Hussain, 2006).

That attempt did not change the relationship between the two governments. In Iran it was presented as a futile effort by the United States to reach the Iranian revolutionary government and in the United States it was seen as an unlawful act by the president to work with an anti-American state in the region (Lovering, 2002).

In the years to come, Iran constantly refused the UN resolution 598 to accept a ceasefire and begin the peace process with Iraq. During the late 1980s the United States continuously requested Iran to accept the UN resolution 598 and Iran constantly refused to do that. "President Reagan ordered a military response: U.S. forces destroyed two Iranian oil platforms, Sassan and Sirri, both important Islamic Revolutionary Guard Corps Navy staging bases" (Crist, 2009). So on 19 October 1987 the United States military attacked two oil wells in the Persian Gulf(LosAngelesTimes., 1987). On 3 July 1988 the U.S.S Vincennes shot an Iranian passenger airplane over the Persian Gulf. The act was seen by the Iranian government as a military treat to Iran while the United States called it a mistake (Mackey and Harrop, 1998).

The Iran-Iraq war created a huge economic, social, and political crisis for Iran. International isolation, the collapse of the Iranian economy, the fall of oil price, the increasing frustration of people with war, and the United States' intervention in the war in late 1987 and early 1988 forced Khomeini to accept the United Nations Security Council Resolution 598 to end the war and save his regime (Marshall, 2003).In order to save the Islamic Republic, on 18 July 1988, "Khomeini grudgingly accepted the (United Nations 598) resolution(Mackey and Harrop, 1998).

Two significant changes occurred in 1989, which influenced Iran's foreign policy. The first was Khomeini's death on 3 June 1989, which gave conservatives and pragmatists the opportunity to become stronger and overcome radical groups (Moslem, 2002). The second was approval of Khamenei as the supreme leader on June $5^{\text {th }}$ (Gasiorowski and Keddie, 1990). Afterwards, the Guardian Council which was controlled by conservatives, called for presidential elections and Rafsanjani who was a pragmatist and the speaker of the Majlis at the time won the election overwhelmingly with only one opponent (Keddie, 2003). 
Additionally, external elements such as: the end of the Iran- Iraq war, the end of the Cold War and disintegration of the Soviet Union had affected Iran's foreign policy.

\section{The Islamic Republic and the US relations (1989-1997)}

Iran's foreign policy during Rafsanjani's presidency focused on the reconstruction of the economy, military and restoring international legitimacy that was lost by Khomeini's radical policies. In order to build Iran's collapsed economy, Rafsanjani tried to engage with the world politically and economically. Iran tried to improve relationships with other countries, especially the Sheikhdoms of the Persian Gulf. Rafsanjani had a pragmatic policy towards the outside world, especially the neighboring countries. While Rafsanjani attempted to rebuild and redefine Iran's foreign policy some factions within the Iranian government and the clergy influenced Rafsanjani's domestic and foreign policy in various ways.

One of these factions was called the "left" or the "radicals". They believed in "anti-imperialism, the export of revolution, and state-sponsored redistributive-egalitarian economic policies". Years later, after the election of Mohammad Khatami to the presidency, the members of this faction became more moderate in their views.

Another influential faction were certain types of conservatives who were most known as the "traditional right". This faction "believes in the sanctity of private property, a minimalist state, a free market economy, and the strict implementation of Shari'a (Islamic Law) in socio-cultural life. Because of its adherence to a highly orthodox interpretation of the Shari'a and its conservative view on economic and socio-cultural questions, this faction was recognized as the "traditional right".

The neo-fundamentalist faction was the fourth category of Iran's influential political forces. This faction "comprised young, highly religious, zealous individuals whose self-proclaimed "holy duty" was to prevent the infiltration of Western cultural norms into the country as well as fighting immorality in the Islamic republic"(Moslem, 2002).

The faction Rafsanjani himself and the supporters of his policies belonged to was the "Modern right". As Moslem describes them the modern rights were "made up mostly of state technocrats whose main objective is politico-economic modernization of the Islamic Republic along the path of developing countries such as the East Asian Tigers as well as maintaining liberal social cultural views. They are labeled "modern" because of their views in the economic sphere and the "right" because of their belief in a free market economy"(Moslem, 2002).

In foreign policy the modern right supported pragmatic policies. Rafsanjani approached in the United States when he "directly addressing himself to the White House ... indicated that the problem of hostages (of February 1988 in Lebanon) had a peaceful solution. He also admitted that the behavior of the Bush administration was 'wiser' than that of the previous administration ... He also again renewed his offer that Iran would use its influence to gain the release of (the United States) hostages if America released Iranian assets and ended its hostile attitude toward Iran"(Hunter, 1990). 
Considering the presence of the United States military in the Persian Gulf, Rafsanjani tried to change Iranian radical policies and behavior to a more pragmatic one and also decrease the tension between Iran and the United States.

Following the end of the Iran-Iraq war, US trade restrictions were slightly relaxed under the Bush administration; "[I]n 1989 [...] the US removed some of its prior trade restrictions and agreed to release close to US\$600 million of Iran's frozen assets in the US. In late 1991, Bush allowed a limited amount of Iranian crude oil into the United States [...] US allies in Europe were also more openly conducting business with Iran"(Estelami, 1999). Indeed president George W. H Bush showed some tendency to improve relationship with Iran(Poolack, 2006).

However, the United States remained suspicious and kept on pressing its allies to restrict transfer of technology and armaments to Tehran until the Iranian government changed its policy toward Washington (Yazdani and Hussain, 2006). The Bush administration insisted that Iran developed weapons of mass destruction, supported terrorism, opposed the Arab-Israel peace process, and finally Iran violated human rights (Ramazani, 1992).

In this period Khamenei's foreign policy was in contrast to that of Khomeini's whose policies were often radical. During the first term of the Rafsanjani presidency Khamenei supported the president's pragmatic policy. As Mehdi Moslem mentions Khamenei "supported the President on all important issues, signaling his approval of the new direction of the Islamic Republic espoused by Rafsanjani and thus taking part in the de-revolutionaization of post-Khomeini Iran"(Moslem, 2002). The Rafsanjani pragmatic policy was not acceptable for the radicals and they attacked him and the Supreme leader. For example one of powerful figure of radical fraction, Mohtashami, attacked supreme leader and his policies "branding them as the new hypocrites' whose real aim was to re-establish relations with the 'American lackeys' in the region and to 'weaken the polices defined by Imam Khomeini'" (Ehteshami, 1995). But the radical leftists strong criticism did not affect on Iran's foreign policy(Moslem, 2002).

The radical left could not succeed in radicalizing Iran's foreign policy. The "traditional right" who supported the supreme leader won the majority of Majlis seats in 1992 and stopped Rafsanjani's foreign policy in relationship with western countries, especially the United States (Zahedi, 2000). The Supreme leader was supported by the majority of his followers in the Majlis and he gradually showed his opposition to Rafsanjani's policies. Khamenei preferred "a reasonable distance between Iran and the West and opposed any Westernization of Iranian society. To prevent 'corruption' of Muslim Iran, he frequently spoke against foreign investment in Iran and his perceptions had an impact on Tehran's foreign policy" (Ehteshami and Hinnebusch, 2002).

In order to stop Rafsanjani's policies toward the West and neighboring countries the traditional right acted like the radical left. "In 1992, four Iranian Kurdish oppositionists were killed at Mykonos restaurant in Berlin. German police investigations traced the killing to high Iranian officials" (Keddie, 2003). Iran did not accept any responsibility for the Mykonos Affair. In reaction the countries who were the members of the European Union decided to 
close their embassies in Tehran.

The opposition to Rafsanjani that consisted of the radical left and the traditional right did not oppose all his decisions on foreign policy. The traditional right had the majority in the Majlis during Rafsanjani's second term but it did not create any problem for Rafsanjani when he decided to expand Iran's relationship with Persian Gulf states or Muslim countries (Moslem, 2002). The opposition from the traditional right started when Rafsanjani decided to engage with the world - including the United States - in order to develop the country and re-build the Iranian economy that had been devastated by the eight-year-long Iran-Iraq war. In 1994 Rafsanjani described his idea of relationship with the United States thus: "I have always been opposed to completely breaking our ties with the United States. They provide us with much needed spare parts and we sell them petrol. Therefore, our economic ties have never been completely halted and some kind of dialogue must always exist. Although we pursue pragmatism in foreign policy, we will not be the first to initiate further dialog with the Americans. They must first show good will by unfreezing our assets in America" (Ettelaatnewspaper., 1994). Such clear expression of willingness to rekindle the relationship with the United States was unheard of for many years. Rafsanjani showed how much he believed in direct negotiation and full diplomatic relationships with the United States (Moslem, 2002).

This was not acceptable to the traditional right. Their opposition to Rafsanjani was strong. As Moslem describes it "As far as the conservatives were concerned, better relations with the United States signified the return of former citizens and possibly prerevolutionary industrialists, Western cultural infiltration, more industrialization, and the demise of the commercial bourgeoisie" (Moslem, 2002). Due to the roots of the traditional right in the Iranian traditional commercial bourgeoisie, mostly known as Bazaar, it was not in the interest of the traditional right to have Iran in direct relationship with the United States. The traditional Right controlled the "Bonyad Mostazafan" ("Dispossessed Foundation"), the largest non-governmental organizational foundation in Iran directly managed by the supreme leader (Thaler et al., 2010).

The traditional right did not see any possibility of competing with American companies in case the relationship could be restored so it was in strong opposition to any attempt in that direction. In such a political situation, Khamenei took the side of the traditional right. 'Factional Politics in Post-Khomeini Iran' "was more willing to intervene in the affairs of the country after 1994: he began to take the conservatives' side in the conflict between Rafsanjani and the conservatives in order to strengthen the position of the traditional right faction. He used his power as a faqih, for instance, to reappoint the controversial pro-conservative Rafiqdoost as the head of the (Dispossessed Foundation) many times. (Khamenei) kept the arch conservative Rezai as head of the IRGC until October 1997, and he replaced Rafsanjani's brother with a known Mo'talefeh(conservative) member, Larijani, as the director of the national radio and TV in 1992" (Moslem, 2002).

Consequently, Rafsanjani decided to fight back against the traditional right. In this fight he allied himself with parts of the radical left. The radical left "soon came to the realization that 
if they were to survive, they needed to: 1) moderate their stance [if only rhetorically]; and 2) exploit the growing gap within the revisionist camp (conservatives and pragmatists). Already, it was clear that Rafsanjani's liberalizing policies on culture were contributing to an ever widening rift between moderates and conservatives. Beginning in 1995, (radicals) took a much more conciliating stance toward centrists and moderates"(Wells, 1999).

Reacting against the traditional right, Rafsanjani and his new allies won the majority of Majlis seats in1996. In the next act, Rafsanjani and his supporters tried to align themselves with a politician within the establishment, who opposed the traditional right and had a chance to win the next presidential election. "In December (of 1996), it had become clear that the new coalition had gained the upper hand and needed to agree on a common (presidential) candidate. In January, the various factions (of this camp) announced that they would back the candidacy of Hojatalislam Khatami. (This choice) was a slap in the face of the conservatives (because) Khatami was the former minister of Islamic Guidance who had been forced out of power by conservatives in 1992. He had served in (radical) Musavi's cabinet and was formerly a supporter of Khamenei's chief rival, (former nominee to succeed Khomeini) Montazeri" (Wells, 1999).

It is said that the supreme leader played a major role in opposing Rafsanjani's foreign policy toward the United States and his economic policy as this would have opened the door to foreign investments (Moslem, 2002).

\section{Conclusion}

During Rafsanjani's presidency, the United States, utilizing "Dual Containment" imposed some sanctions against Iran, such as: the Iran-Iraq Arms Non-proliferation Act of 1993, banning any transfer that aided Iranian or Iraqi attempts to acquire chemical, biological, nuclear, or destabilizing numbers and types of advanced conventional weapons; the executive order of 15 March 1995, which prohibited a United States citizen from entering into contracts for financing or overall management or supervision of the development of petroleum resources located in Iran or in an area over which Iran claims jurisdiction; the executive order of 6 May 1995 prohibited the export of goods, technology, or services, including trade financing by U.S. banks from the United States to Iran; the 5 August 1996 signing of the Iran and Libya Sanctions Act,; the executive order of 19 August 1997, which clarified the previous orders and confirmed that virtually all trade and investment activities with Iran by the United States persons, wherever located, were prohibited (Fayazmanesh, 2003a). In fact, the goal of the United States was to cripple Iran's economy and not to allow Iran to appear as a power in the region (Alam, 2000), and to isolate Iran politically, economically and militarily (Rakel, 2007).

In sum, Rafsanjani, with a pragmatic policy saved Iran from isolation. Iran engaged with most neighbors (Persian Gulf States) and western countries. Indeed, connected to regional organization such as: The United Nations, The Organization of the Islamic Conference (OIC) and The Economic Cooperation Organization. But in relations with the United States, the conservative groups and figures such as Khameini blocked Rafsanjani's foreign policy during his second term. 


\section{Macrothink \\ Journal of Public Administration and Governance \\ ISSN 2161-7104 \\ 2016, Vol. 6, No. 4}

\section{References:}

Abrahamian, E. 1982. Iran between Two Revolution New Jersy, Princeton University Press.

Abrahamian, E. 1999. Tortured Confessions: Prisons and Public Recantations in Modern Iran California, University of California Press.

Afkhami, G. R. 2009. The Life and Times of the Shah, Berekly, University of California.

Alam, S. 2000. The changing paradigm of Iranian foreign policy under Khatami. Strategic Analysis, 24, 24.

Alvandi, R. 2012. Nixon, Kissinger, and the Shah: The Origins of Iranian Primacy in the Persian Gulf. Diplomatic History, 36, 35.

Amin, C. M. 2001. Selling and Saving "Mother Iran": Gender and the Iranian Press in the 1940s. International Journal of Middle East Studies, 33, 26.

Bakhash, S. 1985. The Reign of the Ayatollahs: Iran and the Islamic Revolution London, Tauris.

Brzezinski. 1983. Power and Principle: Memoirs of the National Security Adviser, 1977-1981, New York, Farrar Straus \& Giroux.

Byman, D. 2008. Iran, Terrorism, and Weapons of Mass Destruction. Studies in Conflict \& Terrorism, 31, 12.

Coughlin, C. 2010. Khomeini's Ghost: The Iranian Revolution and the Rise of Militant Islam, London, Pan.

Crist, D. B. 2009. Gulf of Conflict: A History of U.S.- Iranian Confrontation at Sea. the Washington Institute for Near East Policy, 32.

Cronin, S. 1994. Opposition to Reza Khan within the Iranian Army, 1921-26. Middle Eastern Studies, 30, 26.

Ehteshami \&Hinnebusch, R. A. 2002. The Foreign policies of Middle East states, Lynne Rienner Publishers.

Ehteshami, A. 1995. After Khomeini: The Iranian Second Republic, London, Routledge.

Ehteshami. 1995. After Khomeini:The Iranian Second Republic, London, Routledge.

Eisenhower, J. 1991. Schwarzkopf: Desert Storm And Before. http://articles.chicagotribune.com/.

Estelami, H. 1999. A Study of Iran's Responses to U.S. Economic Sanctions. Middle East Review of International Affairs, 3, 10.

Ettelaatnewspaper. 1994. Ettelaat newspaper.

Farber, D. 2009. Taken Hostage: 
The Iran Hostage Crisis and America's First Encounter with Radical Islam, New Jersy, Princeton University Press.

Fardust, H. \&dareini, A. A. 1999. Rise and Fall of the Pahlavi Dynasty, Motilal Banarsidass.

Fayazmanesh, S. 2003a. The Politics of the U.S. Economic

Sanctions against Iran. Review of Radical Political Economics, 35, 19.

Fayazmanesh, S. 2003b. What Kermit Roosevelt Didn't Say. http://www.counterpunch.org/2003/08/18/what-kermit-roosevelt-didn-t-say/.

Gasiorowski, M. J. 1987. The 1953 Coup D'etat in Iran. International Journal of Middle East Studies, 19, 25.

Gasiorowski, M. J. \&Keddie, N. R. 1990. Neither East Nor West: Iran, the Soviet Union, and the United States, New Haven\&London, Yale University Press.

Ghaneabassiri, K. 2002. U.S. Foreign Policy and Persia, 1856-1921. Iranian Studies, 35, 30.

Hindy, S. K. 1981. Internal Conflict Splits Iran's Leader. The Ledger, p.8.

http://www.gwu.edu. 1999. 20 Years after the Hostages:Declassified Documents on Iran and the United States.

Hunter, S. 1990. Iran and the world: continuity in a revolutionary decade, Indiana University Press.

Husain, A. 1988. The revolution in Iran, Rourke Enterprises.

Kechichian, J. A. 1989. The Gulf Cooperation Council: containing the Iranian revolution. South Asian Of Middle Eastern Studies, 8, 19.

Keddie, N. R. 2003. Modern Iran: Roots and Results of Revolution, New Haven\&London, Yale University Press.

Kinzer, S. 2003. All the Shah's Men, New Jersy, John Wiley \& Sons.

Kissinger, H. 2011. Diplomacy, Simon \& Schuster.

Ladjevardi, H. 1983. The Origins of U.S. Support for an Autocratic Iran. International Journal of Middle East Studies, 15, 14.

Lesch, D. W. 2007. The Middle East And the United States: A Historical And Political Reassessment, Colorado, Westview Press.

Losangelestimes. 1987. U.S. Destroys 2 Iranian Oil Platforms in Gulf. http://articles.latimes.com.

Lovering, S. 2002. President Reagan and Tehran - Contra Affair A Lesson in Leadership Failures. LBJ JOURNAL OF PUBLIC AFFAIRS, XIV, 9.

Mackey, S. \&Harrop, S. 1998. The Iranians: Persia, Islam and the Soul of a Nation, New 
York, Plume.

Marshall, C. 2003. Iran's Persian Gulf Policy: From Khomeini to Khatami London, New York, Routledge.

Millspaugh, A. C. 1946. Americans in Persia, Brookings Institution.

Moaddel, M. 1989. State-centered vs. Class-centered perspectives on international politics: The case of U.S. and British participation in the 1953 coup against premier Mosaddeq in Iran. Studies In Comparative International Development, 24, 20.

Moin, B. 1999. Khomeini: Life of the Ayatollah, New York, I. B. Tauris.

Moslem, M. 2002. Factional politics in post-Khomeini Iran, New York, Syracuse University Press.

Mottahedeh, R. 2000. The Mantle of the Prophet, Boston, Oneworld Publications.

Poolack, E. 2006. Stalin and the Soviet Science Wars, New Jersey, Princeton University Press.

Rakel, E. P. 2007. Iranian Foreign Policy since the Iranian Islamic Revolution: 1979-2006. Perspectives on Global Development and Technology, 6, 29.

Ramazani, R. K. 1982. The United States and Iran: The Patterns of Influence, New York, Praeger Publishers.

Ramazani, R. K. 1992. Iran's Foreign Policy: Both North and South. Middle East Journal, 46, 19.

Roosevelt, K. 1979. Countercoup: The Struggle for the Control of Iran, Mcgraw-Hill.

Samii, K. A. 1987. Truman against Stalin in Iran: A Tale of Three Messages. Middle Eastern Studies, 23, 12.

Seikal, A. 1980. The Rise and Fall of the Shah: Iran from Autocracy to Religious Rule, New Jersy, Princeton University Press.

Shawcross, W. 1989. The Shah's Last Ride, New York, Touchstone.

Shirley, E. 1999. Know Thine Enemy: A Spy's Journey into Revolutionary Iran, Colorado, Farrar Straus \& Giroux.

Thaler, D. E., Nader, A., Chubin, S., Green, J. D., Lynch, C. \&Wehrey, F. 2010. Mullahs, Guards, and Bonyads An Exploration of Iranian Leadership Dynamics, Santa Monica, Rand.

Todd, A. \&Marty, M. E. 2005. Ayatollah Khomeini (Spiritual Leaders and Thinkers), Chelsea House Publishers.

Wells, M. C. 1999. Thermidor in the Islamic Republic of Iran: The Rise of Muhammad Khatami. British Journal of Middle Eastern Studies, 26, 12.

www.hamshahrionline.ir 2009. Mohammad Mosaddeq Biography. www.hamshahrionline.ir. 


\section{Macrothink}

Journal of Public Administration and Governance ISSN 2161-7104 2016, Vol. 6, No. 4

Yazdani, E. \&Hussain, R. 2006. United States' Policy towards Iran after the Islamic Revolution:An Iranian Perspective. International Studies, 43, 22.

Zahedi, D. 2000. The Iranian Revolution Then And Now: Indicators Of Regime Instability, Westview Press.

\section{Copyright Disclaimer}

Copyright for this article is retained by the author(s), with first publication rights granted to the journal.

This is an open-access article distributed under the terms and conditions of the Creative Commons Attribution license (http://creativecommons.org/licenses/by/3.0/). 